\title{
Climatic Limits of Wheat Cultivation
}

Author(s): J. D. Falconer

Source: The Geographical Journal, Vol. 39, No. 6 (Jun., 1912), p. 619

Published by: geographicalj

Stable URL: http://www.jstor.org/stable/1778211

Accessed: 11-04-2016 03:15 UTC

Your use of the JSTOR archive indicates your acceptance of the Terms \& Conditions of Use, available at

http://about.jstor.org/terms

JSTOR is a not-for-profit service that helps scholars, researchers, and students discover, use, and build upon a wide range of content in a trusted digital archive. We use information technology and tools to increase productivity and facilitate new forms of scholarship. For more information about JSTOR, please contact support@jstor.org.

The Royal Geographical Society (with the Institute of British Geographers), Wiley are collaborating with JSTOR to digitize, preserve and extend access to The Geographical Journal 
MEETINGS OF ROYAL GEOGRAPHICAL SOCIETY, SESSION 1911-1912. 619

\section{CORRESPONDENCE.}

\section{Climatic Limits of Wheat Cultivation.}

Wirn reference to Dr. Unstead's paper on the "Climatic Limits of Wheat cultivation" in the May number of the Geographical Journal, and Mr. Kitson's remarks thereon, may I say that wheat is grown at the present day in many parts of Northern Nigeria. I have frequently used as an article of food wheaten meal of native production, and I am now sorry that I did not record systematically the various localities in which it may be obtained. Barth, however, in his 'Travels in Central Africa,' gives numerous references to the cultivation of wheat in Bornu, and mentions also the production of both wheat and barley in the neighbourhood of Timbuktu.

There is little doubt that large tracts of country in the Benue valley, in Hausaland, and in Bornu are suitable for the cultivation of wheat. Extensive stretches of these lands are annually flooded during the rains, and owing to the nature of the soil undergo a very gradual desiccation at the beginning of the dry season.

J. D. FALCONER.

\section{MEETINGS OF THE ROYAL GEOGRAPHICAL SOCIETY,} SESSION 1911-1912.

\section{RESEARCH DEPARTMENT.}

April 18, 1912.

"Study of Morocco." By A. Grant Ogilvie.

Twelfth Meeting, April 22, 1912. Major Leonard Darwin, Vice-President, in the Chair.

Elections.-Otto Beit ; R. P. Bishop; Miles Arthur Hall; Charles Fredk. Wm. IIalliley; George L. Harrison; Walter Hutchinson; Robert Wylie Lloyd; David Williamson Moncur; James Henry Worthington, M.A.; Frederic Bosworth Scammell.

The paper read was :-

"Southern Nigeria." By A. E. Kitson.

Thirteenth Meeting, May 6, 1912.-Earl Cunzon of Kedieston, G.C.S.I., etc., President, in the Chair.

Euections.-Hugh Potter Baker; Major Brereton Dew, C.I.E. (Indian Army); Carl Eberstein; Alihrur Ardeshir Engineer, M.A., LL.B. ; S. W. Dorsey; E. English; John Calvin Fergusson; F. W. Grantham; Edward B. Hart; Colonel John Grasson Harwood; Captain Charles Edward Heartt; Piroshaw Bomanji Jujeebhoy Jujeebhoy ; Captain G. W.R. Jenkins ; Ronald Johnstone, C.E. ; Lieut. C. T. Kergwin, R.N.R. ; John H. M. Kirlwood; W. Forbes Leslie; Herbert James Ling; Osborne W. Morgan; Donald Baxter Macmillan; Rev. Henry Edward Newton; Captain Lawrence; Edward Grace Oates; Richard Hubert Pybys; Alfred Richard C. Richings; Lieut. Hugh Jas. Patericl. Segrave (Wiltshire Regt.); Alex. John Stewart; Kung Tien-ch'eng; Alfred Marston Tozzer ; Captain James Leslie Rose Weir, I.A.; Captain John Henry Reginald Yardley (Royal Innis. killing Fusiliers).

The paper read was :-

"United Nigeria." By C. L. Temple, c.M.G. (Secretary of Northern Nigeria Protectorate). 